\title{
Leaf area index mapping with optical methods and allometric models in SMEAR flux tower footprint at Järvselja, Estonia
}

\author{
Marta Mõistus $^{1^{*}}$ and Mait Lang ${ }^{1,2}$
}

\begin{abstract}
Mõistus, M., Lang, M. 2015. Leaf area index mapping with optical methods and allometric models in SMEAR flux tower footprint at Järvselja, Estonia. - Forestry Studies | Metsanduslikud Uurimused 63, 85-99. ISSN 1406-9954. Journal homepage: http:// mi.emu.ee/forestry.studies
\end{abstract}

\begin{abstract}
Leaf area index (LAI) characterizes the amount of photosynthetically active tissue in plant canopies. LAI is one of the key factors determining ecosystem net primary production and gas and energy exchange between the canopy and the atmosphere. The aim of the present study was to test different methods for LAI and effective plant area index (PAI $)$ estimation in mixed hemiboreal forests in Järvselja SMEAR Estonia (Station for Measuring Ecosystem-Atmosphere Relations) flux tower footprint. We used digital hemispherical images from sample plots, forest management inventory data, allometric foliage mass models, airborne discrete-return recording laser scanner (ALS) data and multispectral satellite images. The free ware program HemiSpherical Project Manager (HSP) was used to calculate canopy gap fraction from digital hemispherical photographs taken in 25 sample plots. PAI was calculated from the gap fraction for up-scaling based on ALS point cloud metrics. The all ALS pulse returns-based canopy transmission was found to be the most suitable lidar metric to estimate PAI in Järvselja forests. The 95-percentile $\left(H_{95}\right)$ of lidar point cloud height distribution correlates very well with allometric regression models based LAI and in birch stands the relationship was fitted with $0.7 \mathrm{~m}^{2} \mathrm{~m}^{-2}$ residual error. However, the relationship was specific to each allometric foliage mass model and systematic discrepancies were detected at large LAI values between the models. Relationships between the spectral reflectance and allometric LAI were not good enough to be used for LAI mapping. Therefore, airborne laser scanning data-based PAI map was created for areas near SMEAR tower. We recommend to establish a network of permanent sample plots for forest growth and gap fraction measurements into the flux footprint of SMEAR Estonia flux tower in Järvselja to provide consistent up to date data for interpretation of the flux measurements.
\end{abstract}

Key words: leaf area index, airborne lidar, hemispherical images, multispectral satellite images, SMEAR.

Authors' addresses: ${ }^{1}$ Tartu Observatory, 61602 Tõravere, Tartumaa, Estonia; ${ }^{2}$ Institute of Forestry and Rural Engineering, Estonian University of Life Sciences, Kreutzwaldi 5, 51014 Tartu, Estonia; *e-mail: marta.moistus@to.ee

\section{Introduction}

The aim of the SMEAR (Station for Measuring Ecosystem-Atmosphere Relations) project (SMEAR Estonia, 2015) is the research and monitoring on atmosphere-biosphere interactions (Noe et al., 2011). The $130 \mathrm{~m}$ high SMEAR Estonia flux tower is established in the south east region in Estonia, at the Järvselja Experimental Forest District. The area contributing to the fluxes depends on height of the flux measurement instruments and wind direction (Leclerc \& Thurtell, 1990) and an approximate flux tower footprint for $80 \%$ flux contribution is over $2 \mathrm{~km}$ in upwind direction when measuring at $90 \mathrm{~m}$ height (Noe, 2013). The estimates of gas fluxes between forest ecosystems and atmo- 
sphere and estimates of emitted volatile organic chemical compounds from forests are closely related to the amount of the photosynthetic organs, stems and branches. Hence, high quality estimates of the forest structure variables are required to interpret the flux measurements. The amount of foliage can be described by leaf area index (LAI) defined by Watson (1947) as the total one-sided area of leaf tissue per unit ground surface area. LAI is one of the key factors determining ecosystem net primary production and energy exchange between land surfaces and the atmosphere (Nikinmaa \& Bäck, 2008).

Leaf area responds to different disturbance factors and is related to forest soil productivity and plant growth (Bréda, 2003). Process-based ecosystem simulation models use LAI as input parameter for forest productivity analyses (Chen et al., 1997; Bréda, 2003). LAI could also serve as a useful indicator to characterize the condition of forest ecosystems for global change studies (Myneni et al., 1997).

The most accurate LAI estimation method is destructive sampling of foliage combined with the estimates based on the local allometric relationships to upscale from the sample plots (Chen et al., 1997; Jonckheere et al., 2004). Since the direct estimation methods (harvesting, allometry, litter collection) are time consuming and laborious, the canopy transmittance analysis-based optical indirect techniques (Chen et al., 1997; Jonckheere et al., 2004) are generally used to estimate LAI. In fact, the outcome of the indirect optical methods is not the true green LAI as defined by Watson (1947) but effective plant area index $\left(\mathrm{PAI}_{\mathrm{e}}\right)$, because of clumping and contribution of stems and branches. Conversion of $\mathrm{PAI}_{\mathrm{e}}$ to true LAI requires data about stems and branches, species-specific estimates of clumping in the canopy within shoots (Stenberg, 1996), within branches, whorls and crowns (Chen et al., 1997), and also information about leaf angle distribution. For deciduous trees the woody part can be estimated by laser scanning during leaf-off period (Béland et al., 2014). The radiative transfer theory (Ross,
1981) is used to estimate LAI from measurements of the transmission of radiation through the canopy. These indirect methods are non-destructive and they are based on a statistical and probabilistic approach to foliar element distribution and arrangement in the canopy (Jones, 1992). More sophisticated methods to calculate true LAI of forest canopy from gap fraction measurements require also stand structure information from forest inventory or sample plots (Nilson, 1999).

Based on direct measurements, allometric regression models can be established to describe the relationships between leaf area and some directly measurable dimensions of the woody plant carrying the green leaf biomass (Jonckheere et al., 2004). Marklund (1988) showed that by using tree stem diameter at breast height $d_{1.3}$, tree height $h$ and living crown length $l c r$ as predictive variables, more than $94 \%$ of single tree foliage mass variation can be explained. The allometric model by Marklund (1988) has been used for biomass calculations in Scandinavian forests and also in regularly managed Scots pine forests in Finland (Kärkkäinen, 2005). However, Lang et al. (2007) found that Marklund (1988) models gave systematically different estimates in Estonia depending on the list of arguments and explained this by the different $d_{1.3}$ to $h$ relationship and different growth conditions in Estonia compared to Sweden. Gower et al. (1999) also found that allometric methods tend to be applicable for a single species in a single geographical area, and when allometric equations are applied to trees of size outside the range of the underlying empirical data of the models, estimation accuracy decreases and systematic errors may occur. However, if up to date forest management inventory data are available, an allometric foliage mass model could be the first choice to create LAI map, since the species composition, mean tree breast height diameter $D_{1.3^{\prime}}$ and stem height $H$ and stand density are the basic descriptive variables of forest stands. On the other hand, allometric foliage mass models are based on single tree data and the estimates are slightly different if individual 
tree foliage mass estimates are aggregated or stand level $D_{1.3}$ and $H$ are used as foliage mass predictor variables (Majasalmi et al., 2013).

Hemispherical photography can be used to measure canopy gap fraction for indirect LAI estimation for a point in forest (Anderson, 1964). A hemispherical image provides permanent record and is therefore a valuable information source about size, density and distribution of canopy gaps (Jonckheere et al., 2004). Canopy gap fraction has been estimated from hemispherical images using a thresholding method to separate the canopy from the sky (Wagner, 1998; Frazer et al., 1999). Both manual and automatic canopy and sky pixel classification methods are highly dependent on photographic exposure, operator experience or assumptions made in thresholding algorithms, and therefore produce rather subjective and non-repeatable results (Rich, 1990; Cescatti, 2007). However, if the canopy image does not contain many mixed pixels of plant elements and sky, then fast automated procedures can be applied. Recently, Macfarlane (2011) found that out-of-camera JPEG format images from eucalyptus stands with LAI up to $2 \mathrm{~m}^{2} \mathrm{~m}^{-2}$ can be reliably automatically processed for LAI estimation. Since the sensors used in modern digital cameras respond linearly to light, it is possible to retrieve an image where the stored digital numbers are proportional to the incident radiation (Cescatti, 2007), which makes the data compatible to data from plant canopy analyzers. By using this feature of modern digital cameras a single camera can replace a pair of plant canopy analyzers (Lang et al., 2010).

There are several methods to estimate LAI from multispectral satellite images. Regular acquisition of multispectral images with scanners onboard Landsat- 8 and Sentinel-2 make the data particularly attractive for monitoring of LAI phenology similarly to Rautiainen et al. (2009). LAI can be estimated via spectral reflectance by using regression models or radiative transfer models. The radiation transfer models developed for the application to remotely sensed optical data rely on physically-based relationships between LAI and canopy spectral reflectance (Liang, 2004; Stenberg et al., 2004; Kuusk et al., 2015). The spectral variable used for the estimation should be sensitive to changes in the target variable (LAI) throughout its natural range (Stenberg et al., 2004).

Active remote sensing techniques, such as airborne lidar, produce data that are directly related to canopy vertical structure, volume, biomass and LAI (Lefsky et al., 1999; Lefsky et al., 2002; Richardson et al., 2009; Korhonen et al., 2011; Pope \& Treitz, 2013). Solberg et al. (2009) showed that PAI can be calculated from airborne lidar (ALS) data-based canopy cover estimates with a simple model. However, ALS data-based canopy cover estimates depend substantially on the selection of different order of echoes (returns) (Solberg et al., 2009; Lang, 2010) and this has direct influences also on $\mathrm{PAI}_{\mathrm{e}}$ estimates. Consequently, the regression model parameters have to be estimated for each ALS data set by using reference measurements from sample plots.

The aim of the study was to test different methods for $\mathrm{PAI}_{\mathrm{e}}$ and LAI estimation for the mixed species hemiboreal forests in Järvselja SMEAR flux tower footprint. While there are no special remote sensing data acquisitions (e.g. ALS measurements) yet carried out for Järvselja SMEAR experiment area, we used already collected ALS data, multispectral satellite images, sample plot measurements from other projects in Järvselja, forest management inventory data and published allometric models for foliage mass. Digital hemispherical images were used to estimate canopy structure indices in forest growth research network sample plots.

\section{Material and Methods}

\section{Study area and sample plots}

The study area is located in Järvselja Experimental Forest District in south east region of 
Estonia (Figure 1). Northern part of the territory extends to the Emajõe Suursoo, which is a large complex of different swamps and mires. The area is situated in the hemiboreal forest zone with a moderately cool and moist climate. The terrain is flat. Forests are managed according to forest management plan and forest inventory data. Forest stands are dominated by Scots pine (Pinus slvestris L.), Norway spruce (Picea abies (L.) Karst.) and Silver birch (Betula pendula Roth). Other species such as Populus tremula L., Alnus incana (L.) Moench, Tilia cordata Mill., Prunus padus L. and Fraxinus excelsior
L. are also common. The species composition in the forests and forest structure is often fairly complex. There are several sample plot-based studies carried out in Järvselja forests. The sample plots located within a distance of $5.4 \mathrm{~km}$ from the SMEAR flux tower $\left(58^{\circ} 16.7^{\prime} \mathrm{N}, 27^{\circ} 18.5^{\prime} \mathrm{E}\right)$ were originally established for forest growth modelling (Kiviste \& Hordo, 2002; Kangur et al., 2005; Kiviste et al., 2015). Tree measurement data from eight of the sample plots have been earlier used in VALERI (Validation of Land European Remote sensing Instruments, 2015) project by Kodar et al. (2011).

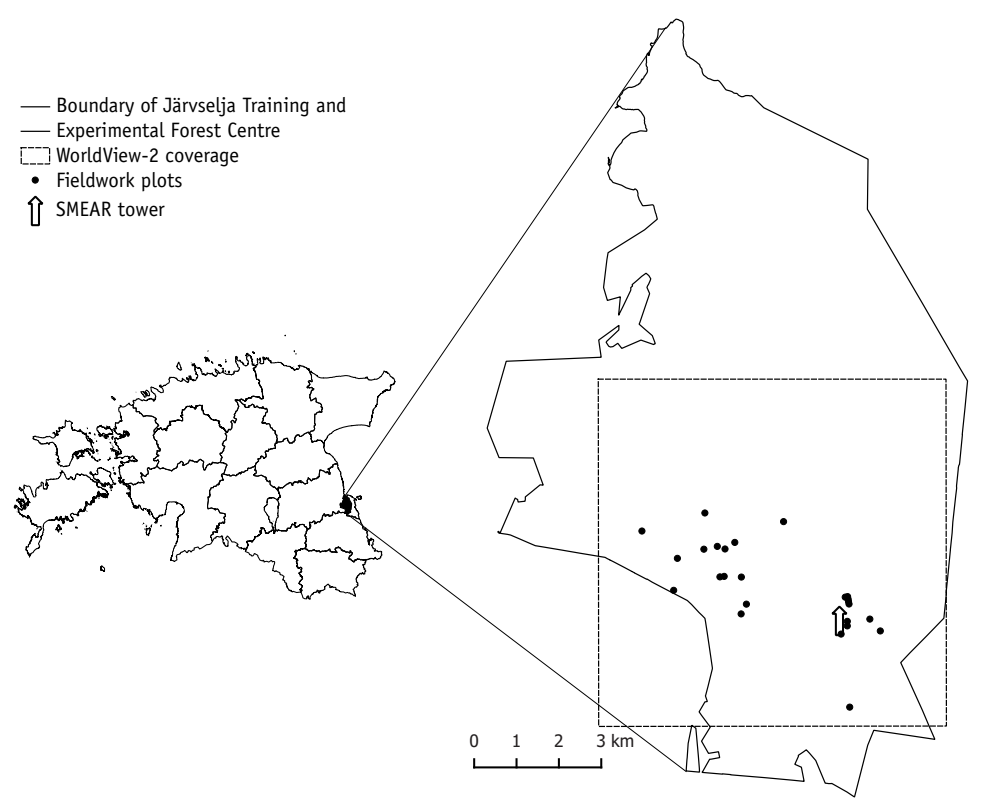

Figure 1. The study site and location of fieldwork sample plots (dots) and SMEAR tower (arrow) in Järvselja. Joonis 1. Maapealsete mõõtmiste asukohad Järvseljal. Pidevjoonega on tähistatud Järvselja Õppe- ja Katsemetskonna piir ning punktiiriga WorldWiew-2 pildi katvusala. Täpid kujutavad proovialade ja nool SMEAR-masti paiknemist.

Table 1. General description of sample plots used for gap fraction measurements.

Tabel 1. Metsa läbipaistvuse mõõtmiseks kasutatud proovitükkide üldkirjeldus.

\begin{tabular}{lccc}
\hline $\begin{array}{l}\text { Variable / } \\
\text { Tunnus }\end{array}$ & Statistic / & $\begin{array}{c}\text { Deciduous / } \\
\text { Sehtpuupuistud }\end{array}$ & $\begin{array}{c}\text { Coniferous / } \\
\text { Okaspuupuistud }\end{array}$ \\
\hline Forest age (years) & Min & 14 & 4 \\
Metsa vanus (aastat) & Mean & 58 & 91 \\
& Max & 109 & 184 \\
\hline Basal area $\mathrm{m}^{2} /$ ha & Min & 4.5 & 0.5 \\
Rinnaspindala & Mean & 22.0 & 23.7 \\
& Max & 32.0 & 30.0 \\
\hline
\end{tabular}




\section{Allometric LAI for forest stands}

Järvselja forests have been inventoried for forest management planning since 1922 with 10-year interval. Forest management inventory data from year 2010 and the foliage mass models by Marklund (1988) and by Repola $(2008,2009)$ were used to calculate allometric LAI for the forest stands in Järvselja Forest inventory database. These models predict single tree foliage dry mass based on the tree stem breast height diameter and tree height. The LAI for tree layer $L A I_{\text {trees }}$ in each forest stand was calculated by using the estimated allometric foliage mass, stand density from forest inventory database and specific leaf weight (SLW, g/ $\mathrm{m}^{2}$ ) using the same SLW values as Lang et al. (2007). Total forest LAI was calculated as $L A I_{\text {trees }}+L A I_{u}$ where forest understory vegetation $L A I_{u}$ was calculated with the model $L A I_{u}=2.4-0.44 L A I_{\text {trees }}$ taken from Figure 3 in Kodar et al. (2011). For detailed analysis a set of forest stands larger than 2 hectares was selected from around the SMEAR Estonia flux tower.

\section{Digital hemispherical images}

Digital hemispherical photographs (DHPs) were collected in August 2014 from 25 sample plots (Figure 1). Unfortunately, for three sample plots up to date tree measurement data was not available and the sample plots were removed from the analysis. The images were taken with Canon EOS 5D digital camera and fisheye lens Sigma $8 \mathrm{~mm}$ F3.5 EX DG. The camera was calibrated in Tartu Observatory's optical laboratory (Lang et al., 2010). The camera was set to take raw files in order to obtain linear data comparable to plant canopy analyzers (Cescatti, 2007; Lang et al., 2010). At each sample plot, three DHPs were taken in four different directions (north, south, east and west) with a distance of five meters between each take (Validation of Land European Remote sensing Instruments, 2015; Figure 2 in Kodar et al., 2011). In total, 12 hemispherical photos from below canopy and one image with lens completely covered per one forest growth sample plot were taken. The dark image signal was later subtracted from below canopy images to remove sensor signal offset. Images were taken at breast height (about $1.3 \mathrm{~m}$ ) using tripod. The camera was leveled and oriented so that the top of the image was always facing north. The images were taken during overcast or before sunrise or after sunset. However, later during image processing we found signs of direct illumination on some images due to rising Sun.

The hemispherical images were processed using free ware program HemiSpherical Project Manager (HSP) (Lang et al., 2013). In HSP, canopy gap fraction can be calculated in similar to plant canopy analyzers by first restoring the above canopy image from below canopy image by interpolating sky pixel samples from canopy gaps over the hemisphere. The gap fraction was computed for zenith angles from $0^{\circ}$ to $90^{\circ}$ with $4.5^{\circ}$ annuli and averaged over all azimuth angles and 12 images for each sample plot. The Miller's (1967) integral was used to calculate effective plant area index $\mathrm{PAI}_{\mathrm{e}}$ :

$P A I_{e, \mathrm{DHP}}=-2 \int_{0}^{\pi / 2} \ln (\mathrm{T}(\theta)) \cos \theta \sin \theta d \theta$,

where $T(\theta)$ is azimuthally averaged transmittance from hemispherical images at view zenith angle $\theta$. No further corrections were made to the $P A I_{e, D H P}$ estimate.

\section{Airborne lidar data}

The ALS data was acquired by Estonian Land Board with Leica ALS50-II instrument in 29 June 2010 covering total area of about $240 \mathrm{~km}^{2}$. The Leica ALS50-II scanner registers up to four returns per emitted pulse. Average pulse return density in the sample plots was $0.32-0.52$ of first returns per $\mathrm{m}^{2}$ (3.21 return $/ \mathrm{m}^{2}$ in one sample plot which situated in overlapping area of two scanning stripes) and $0.35-0.87$ of all returns per $\mathrm{m}^{2}$ (3.62 return $/ \mathrm{m}^{2}$ in overlapping area). The pulse footprint was $0.54 \mathrm{~m}$, scan angle ranged up to 29 degrees from nadir resulting in $1.2 \mathrm{~km}$ wide scanned area on ground during flight. 
FUSION software (McGaughey, 2012) was used for lidar data processing. The point cloud height was normalized by using digital ground elevation model based on the lidar data. Point cloud sample size was chosen to be comparable with the area captured on hemispherical images and the area of the forest sample plots. Within each of these extracted point subsets (cylinders with base radius $20 \mathrm{~m}$ ) following metrics were calculated: the number of first canopy returns above $1.3 \mathrm{~m}\left(P_{1}\right)$, the number of all canopy returns above $1.3 \mathrm{~m}$ $\left(P_{a}\right)$, total returns $\left(P_{t}\right)$, total first returns $\left(P_{t 1}\right)$ and 95-percentile of the point cloud height distribution $\left(H_{95}\right)$. The canopy transmission $T_{\text {lidar }}$ for $\mathrm{PAI}_{\mathrm{e}}$ estimation was obtained by subtracting the cover index from one (Korhonen et al., 2011) and was estimated from all returns and from first returns:

$$
\begin{aligned}
& T_{\text {lidar }, P 1}=1-\frac{\sum P_{1}}{\sum P_{t 1}}, \\
& T_{\text {lidar }, P a}=1-\frac{\sum P_{a}}{\sum P_{t}} .
\end{aligned}
$$

The $T_{\text {lidar }}$ was compared with the gap fraction from DHPs extracted at the same view zenith angle as the lidar scanning nadir view angle. The view angle information for the individual pulse returns was extracted with LasTools toolset (Isenburg, 2007). The scan nadir angle was relatively constant in the sample plots. In one sample plot which was located in overlap area of two measured stripes the scan angle varied between 0 and 24 degrees. To estimate PAI from ALS data the model from Korhonen et al. (2011) was used:

$$
P A I_{e, l i d a r}=\beta(-\ln (T)),
$$

where $\beta$ was estimated by fitting a regression without intercept on $P A I_{e, D H P}$ obtained from Eq. (1) and $T$ was obtained from Eq. (2) or Eq. (3). The model (4) fitting was performed using $\mathrm{R}$ version 3.1.2 (R Development Core Team, 2014). Finally, $\mathrm{PAI}_{\mathrm{e}}$ raster map of $15 \mathrm{~m}$ spatial resolution was created with model (4) for all the area covered by ALS data.

\section{Satellite images}

The satellite images from Landsat-7 Enhanced Thematic Mapper Plus (ETM+), Landsat-8 Operational Land Imager (OLI) and WorldView-2 (Figure 1) were used for analysis. The images were acquired accordingly on 28 August 2011, 21 July 2014 and 29 July 2013. The satellite images were projected into the Estonian basic map coordinate system (EPSG:3301) using nearest neighbor sampling and $15 \mathrm{~m}$ pixel was used for Landsat images and $2 \mathrm{~m}$ pixel was used for WorldView-2 image. Atmospheric correction for the WorldView-2 image was done in Tartu Observatory by A. Kuusk and the image represented top of canopy reflectance. At-sensor radiance was used from Landsat images without atmospheric correction. The areas covered by clouds or cloud shadow were masked.

To examine the dependence of allometric LAI of forest stands on spectral reflectance we tested the following bands: Landsat-7 ETM+ and Landsat-8 OLI red, near infrared (NIR) and shortwave infrared (SWIR) spectral bands; WorldView-2 bands B5 (red, 630-690 nm), B6 (red edge, 705-745 nm), B7 (NIR1, 770-895 nm) and B8 (NIR2, 860-1040 nm). These bands are also commonly used for vegetation indices e.g. NDVI (Normalized Difference Vegetation Index) (Rouse et al., 1973; Liang, 2004).

\section{Results}

\section{PAI $_{e}$ estimation using ALS data}

There was a strong linear relationship $\left(R^{2}=0.629\right)$ between the gap fraction $T_{D H P}$ estimated from hemispherical images and lidar pulse transmission $T_{\text {lidar } P a}$ (Figure 2b). The first pulse return-based transmission $T_{\text {lidar, } P 1}$ was smaller and the relationship with $T_{D H P}$ was much more scattered $\left(R^{2}=\right.$ $0.315)$ as compared $T_{\text {lidar, } P a}$. The results are 
probably influenced by the Leica ALS50-II scanner internal signal processing algorithm which is optimized for topographic mapping of ground surface and records more than one return per pulse if the distribution of the returned signal has multiple modes. The $T_{\text {lidar. }{ }_{a} \text { }}$ was then used to fit regression model (4) for PAI estimation form ALS data. The model $P A I_{e, D H P}=-1.65 \ln \left(T_{\text {lidar, } P_{a}}\right)$ was compared to the LAI model from Kodar et al. (2011) and the estimated PAI was consistently smaller then LAI (Figure 3).
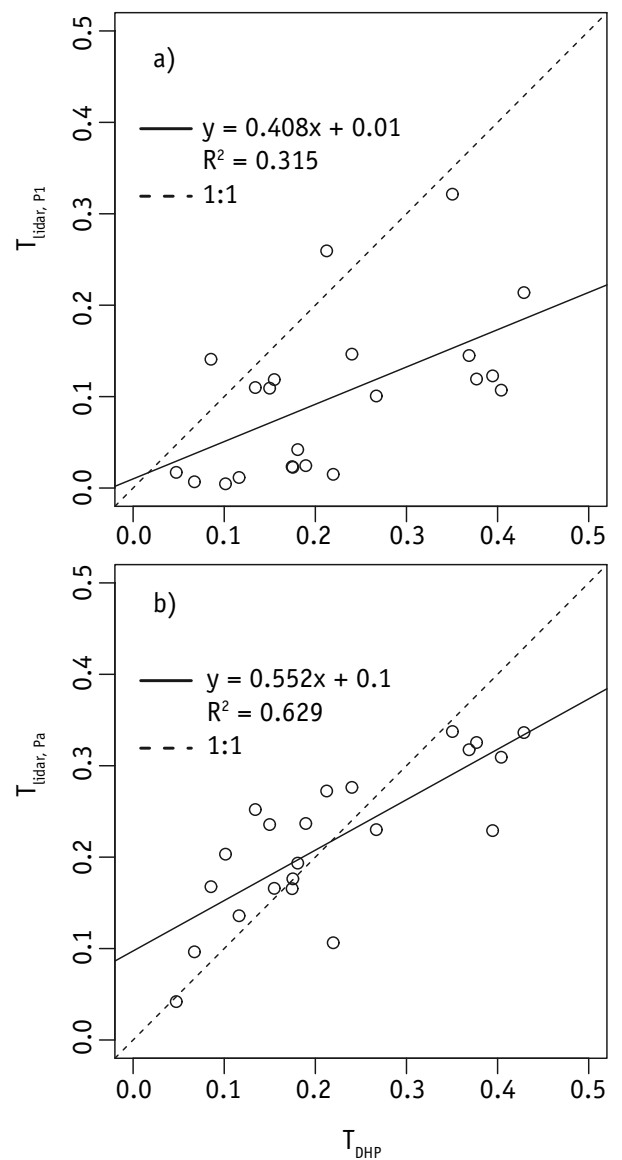

Figure 2. Relationship between canopy transmission estimates from airborne lidar data $\left(T_{\text {lidar }, P_{1},} T_{\text {lidar, }, p}\right)$ and canopy gap fraction estimates form digital hemispherical photographs $\left(T_{\text {DHP }}\right)$ in sample plots.

Joonis 2. Metsa läbipaistvus arvutatuna valemitega (2) ja (3) aerolidari andmetest ( $\mathrm{T}_{\text {lidar, }, \mathrm{P}_{1} \text {, }}$ $\left.\mathrm{T}_{\text {lidar, } \mathrm{Pa}}\right)$ ja poolsfääri piltidelt $\left(\mathrm{T}_{\mathrm{DHP}}\right)$.

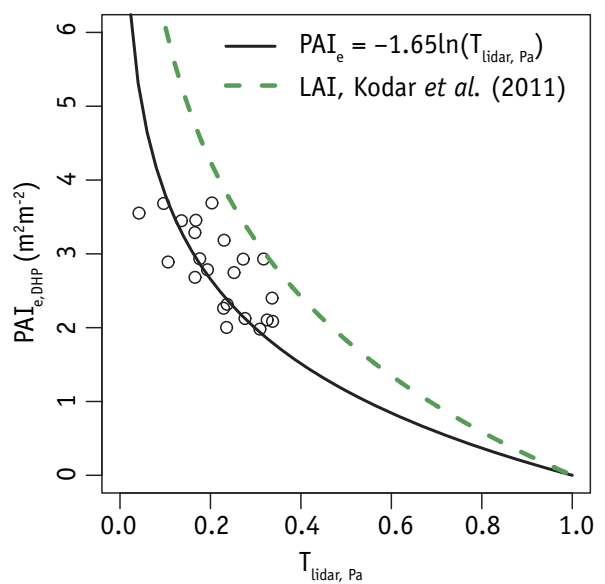

Figure 3. The model for up-scaling of $P A I_{e, D H P}$ from sample plots to all forests in Järvselja based on ALS data. For comparison the LAI model from Kodar et al. (2011) is plotted.

Joonis 3. Valemiga (1) poolfääripiltidelt arvutatud efektiivse taimkatteindeksi PAI $_{\text {e. DHP }}$ seos aerolidari andmetest arvutatud vorrastiku läbipaistvusega $\mathrm{T}_{\text {lidar, pa. Võrdluseks on }}$ toodud Kodar et al. (2011) LAI mudel.

\section{Allometric LAI and ALS-based forest height}

We used Korf-Lundqvist (Korf, 1939) type equation to approximate the relationship between allometric LAI and 95-percentile $\left(H_{95}\right)$ of lidar point cloud height distribution:

$$
L A I_{\text {allometric }}=a_{1} \exp \left(\mathrm{a}_{2} \mathrm{H}_{95}^{\mathrm{a} 3}\right),
$$

where $a_{1}, a_{2}$ and $a_{3}$ are parameters. The estimated values of the model parameters for birch stands are given in Table 2. The model residual error (RSE) for birch stands was $0.64 \mathrm{~m}^{2} \mathrm{~m}^{-2}$ when LAI for trees was estimated with allometric regression model of Repola (2008) and $0.70 \mathrm{~m}^{2} \mathrm{~m}^{-2}$ when Marklund (1988) model was used. Determination coefficient $R^{2}$ was 0.91 and 0.95 respectively. When pine stand data were plotted together with birch stands, a group of old pine stands formed a separate cluster in the scatterplot (Figure 4). It is not clear whether the Repola $(2008,2009)$ and 
Marklund (1988) allometric models are not applicable for the stands or there are errors in $D_{1,3^{\prime}}, \mathrm{H}$ and stand density values in forest inventory database or there could be an informative variable missing from the model (5). For this reason the model (5) was fitted on all stands shown in Figure (4) and the model residuals were correlated with $T_{\text {lidar,Pa }}$. The Pearson correlation coefficient was 0.06 and -0.02 depending on the used allometric foliage mass model and indicated that canopy cover $\left(1-T_{\text {lidar, }, \text { a }}\right)$ was not the informative variable. This was somewhat surprising, since $T_{\text {lidar,Pa }}$ and similar variables are used for upscaling optical indirect measurements-based LAI.

Table 2. Parameters for Korf-Lundqvist type equation (5) to predict allometric LAI of birch stands based on 95-percentile of ALS point cloud height distribution.

Tabel 2. Korf-Lundqvist tüüpi (5) mudeli parameetrid kaasikute allomeetrilise LAI hindamiseks aerolidari impulsi peegelduste kõrgusjaotuse 95-protsentiili järgi.

\begin{tabular}{ccc}
\hline Parameter / & \multicolumn{2}{c}{$\begin{array}{c}\text { Foliage mass model / } \\
\text { Lehemassi mudel }\end{array}$} \\
\cline { 2 - 3 } & Marklund & Repola \\
& $(1988)$ & $(2008)$ \\
\hline$a_{1}$ & 5.4 & 13.7 \\
$a_{2}$ & -9.0 & -8.5 \\
$a_{3}$ & 1.389 & 0.7621 \\
\hline
\end{tabular}

For comparison, we fitted linear regression models for the birch forest data to describe relationship between 1) canopy coverbased $P A I_{e, l i d a r}$ and allometric LAI of trees and 2) SPO'T-4 HRV-IR red band radiancebased $L A I_{\text {HRVIR } 2}$ from Kodar et al. (2011) and allometric LAI of trees plus forest understory LAI. All the regression models were significant. The regression model statistics for $P A I_{e, \text { lidar }}$ and the better performing Marklund (1988) model-based LAI were $R^{2}$ $=0.58$ and $R S E=1.1 \mathrm{~m}^{2} \mathrm{~m}^{-2}$ and for the second test with $L A I_{\text {HRVIR2 }}$ again the Marklund (1988) model performed better $\left(R^{2}=0.45\right.$ and $R S E=0.7 \mathrm{~m}^{2} \mathrm{~m}^{-2}$ ).

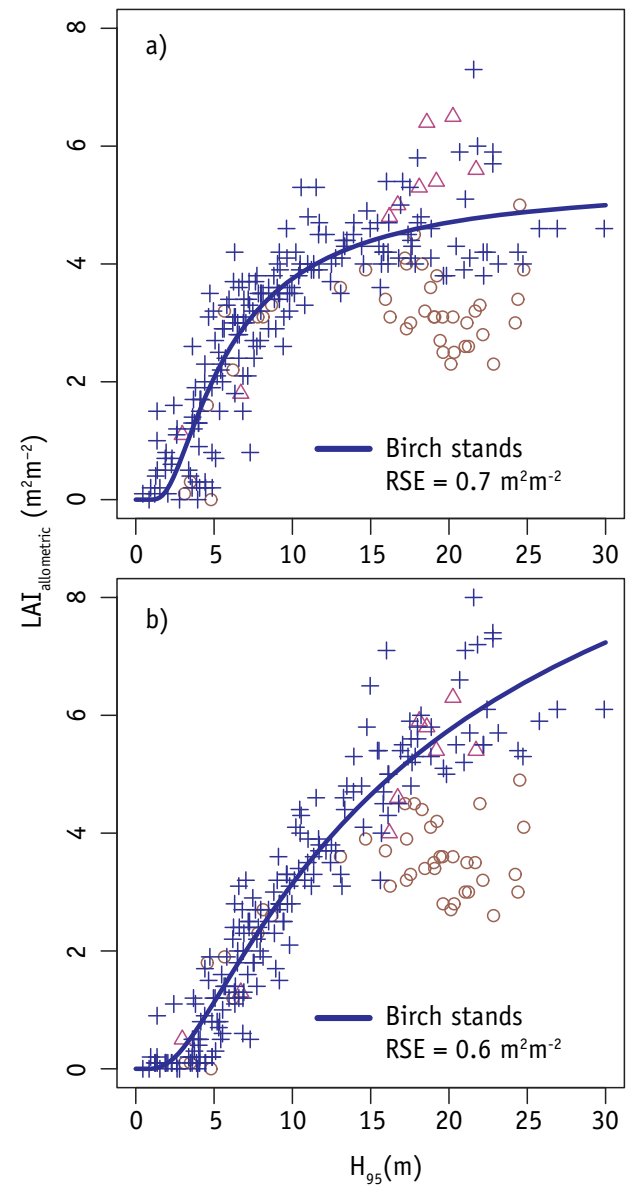

Figure 4. Allometric LAI of birch stands in Järvselja can be well predicted by using 95 -percentile of ALS pulse return height distribution: a) Marklund (1988) model, b) Repola $(2008,2009)$ models. Legend: $\bigcirc-$ pine stand, $\triangle$ - spruce stand, +- birch stand.

Joonis 4. Allomeetrilise LAI ja aerolidari impulsi peegelduste kõrgusjaotuse 95-protsentiili seose kirjeldamiseks Järvselja kaasikutes sobib Korf-Lundqvist tüüpi võrrand (5), mille parameetrite hinnangud on tabelis 2 . a) Marklundi (1988) mudel, b) Repola (2008, 2009) mudelid. Legend: $\bigcirc$ - männik, $\triangle$ - kuusik, +- kaasik.

\section{Allometric LAI and forest spectral reflectance}

The top of canopy reflectance of forest stands when plotted with $L A I_{\text {trees }}+L A I_{u}$ had quite a large scatter and the relationship had clear influence of tree species composi- 
tion of the stands (Figure 5). The most species independent band was red band, however, this did not create options to build a regression model due to large scatter. All the bands had very weak correlation with LAI $\left(R^{2}<0.1\right)$. Only the red edge band (B6) reflectance of Worldview-2 was found to have a relationship with $L A I_{\text {trees }}+L A I_{u}$ for Repola (2008) model-based LAI (Figure 5). However, the relationship reached an asymptote already at LAI $>3$ and there are even some signs of reflectance increase at large $L A I_{\text {trees }}+L A I_{u}(>6)$ values. The relationships between the allometric LAI and NDVI calculated from the WorldView-2 data were very scattered and had low correlation $\left(R^{2}<0.1\right)$.

The spectral radiance in Landsat-7 ETM+ and Landsat-8 OLI bands had only weak correlation with $L A I_{\text {trees }}+L A I_{u}$. The separation between species somewhat improved the correlation with LAI and the best results were in birch stands. The strongest correlation between LAI and spectral radiance was in the SWIR band (by the data of year $2011 R^{2}=0.157$ by Marklund (1988) model and $R^{2}=0.103$ by Repola $(2008,2009)$ models; by the data of year $2014 R^{2}=0.180$ by Marklund (1988) and $R^{2}=0.129$ by Repola $(2008,2009)$ models). Relationship of spectral radiance and $P A I_{e, D H P}$ of sample plots was weak $\left(R^{2}<0.1\right)$. None of the relationships between satellite spectral bands and allometric LAI was good enough to be used for LAI mapping. Therefore, only ALS data and digital hemispherical images were used to construct PAI map.
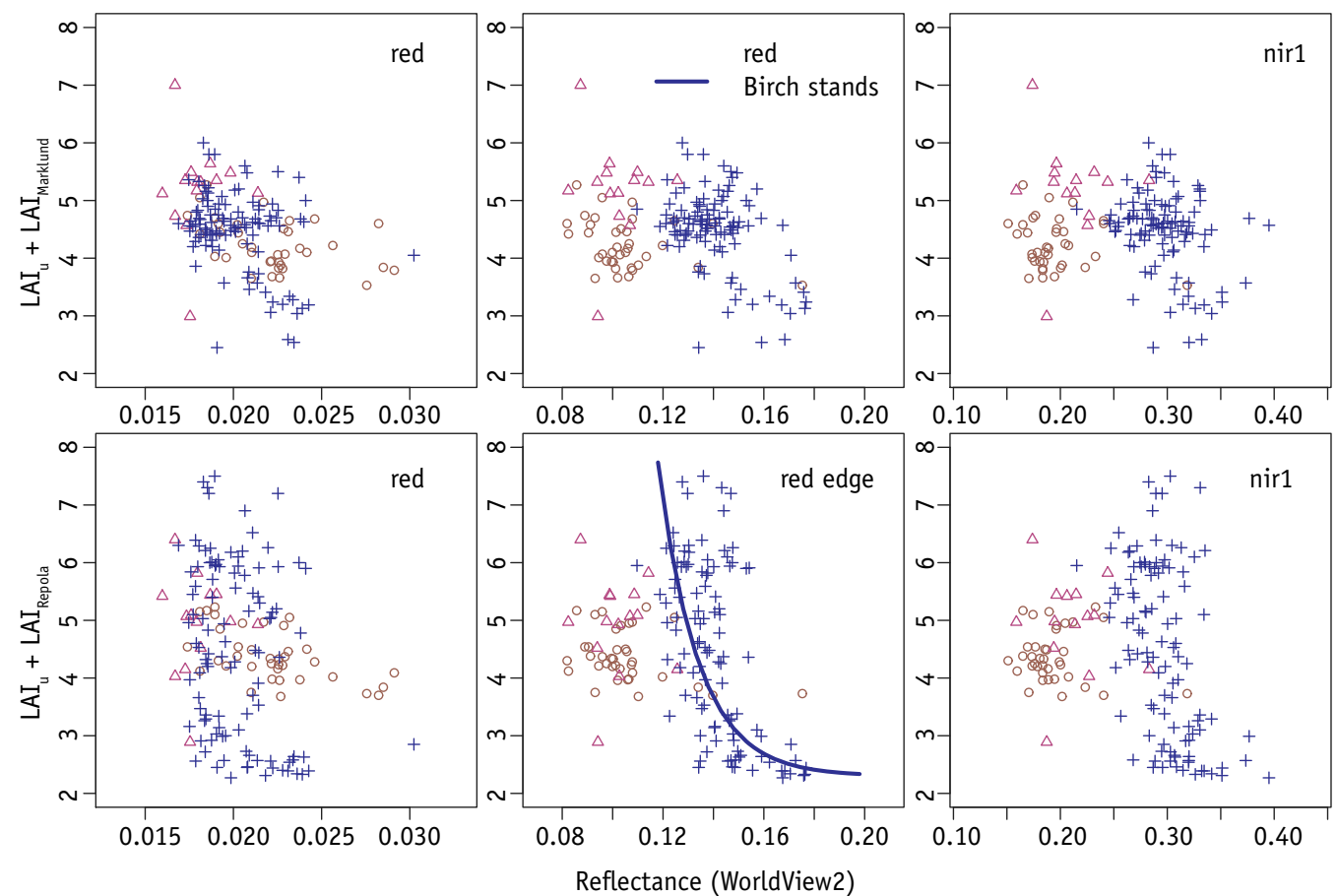

Figure 5. Top of canopy reflectance from WorldView-2 image and forest LAI including forest undergrowth leaf area index $L A I_{u}$. An approximate relationship for birch stands is plotted for red edge band. Legend: $\bigcirc$ - pine stand, $\triangle$ - spruce stand, + - birch stand.

Joonis 5. WorldView-2 pildilt arvutatud spektraalse heleduskoefitsiendi ja allomeetrilise LAI seosed. Legend: $\bigcirc$ - männik, $\triangle$ - kuusik, + - kaasik. 
Comparison of ALS data based $P A I_{e, \text { lidar }}$ with LAI from Kodar et al. (2011)

We compared ALS pulse transmissionbased $P A I_{e, \text { lidar }}$ map from current study and SPOT-4 HRV-IR data-based $L A I_{\text {HRVIR } 2}$ map for Järvselja VALERI test site by Kodar et al. (2011) and found the estimates strongly correlated $\left(R^{2}=0.528\right)$. As expected, $P A I_{e, \text { lidar }}$ was generally smaller than $L A I_{\text {HRVIR2 }}{ }^{\prime}$ because it is an effective value and the plants shorter than $1.3 \mathrm{~m}$ are excluded from the ALS data-based canopy cover estimates in this study. However, at $L A I_{\text {HRVIR } 2}$ values bigger than $4 \mathrm{~m}^{2} \mathrm{~m}^{-2}$ there was a tendency of birch dominated stands to have $P A I_{e, \text { lidar }}$

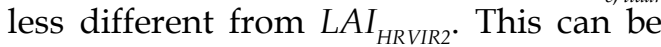
due to the underestimation of LAI or overestimation of PAI in the birch stands. The model used by Kodar et al. (2011) predicts larger LAI with the reflectance decrease in red band. The LAI underestimation can occur when 1) the reflectance of the birch stands in SPOT-4 HRV-IR red band had a

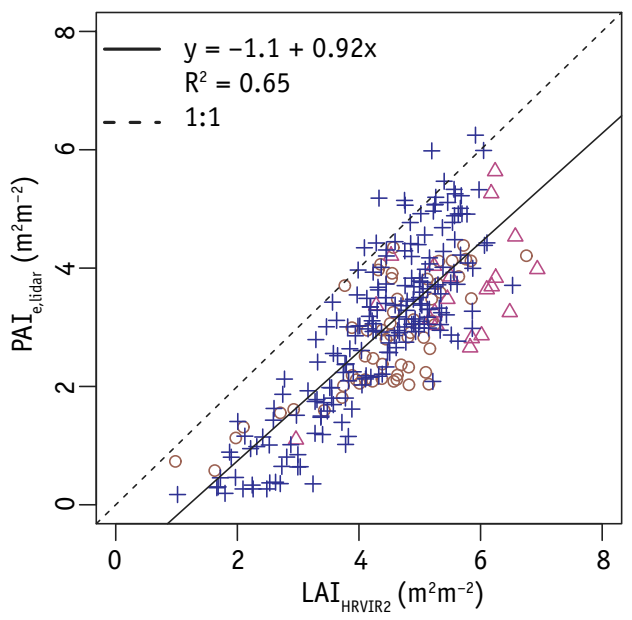

Figure 6. Forest stand LAI values from Kodar et al. (2011) study $\left(L A I_{\text {HRVIR } 2}\right)$ compared to $P A I_{\text {e,lidar }}$ (Eqs. 2, 3 and 4). Legend: $\bigcirc-$ pine stand, $\triangle-$ spruce stand, +- birch stand.

Joonis 6. Kodar et al. (2011) saadud lehepinnaindeksi LAI $_{\text {HRVIR2 }}$ võrdlus käesolevas töös lidarandmete ning poolsfääripiltide põhjal valemite (2), (3) ja (4) järgi puistutele arvutatud $\mathrm{PAI}_{\text {elidar }}$ hinnanguga. Legend: $\bigcirc-$ männik, $\triangle$ e, kuusik, +- kaasik. saturating relationship with LAI or 2) had relatively larger reflectance in the red band compared to the reference data used by

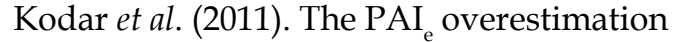
can occur when the birch stands have 1) increased reflectance in NIR spectral region where ALS50-II operates or 2) high canopy cover and short crowns causing relatively more pulse returns to be triggered from the canopy than from the ground.

\section{Discussion}

The usual ALS-based variable for $\mathrm{PAI}_{\mathrm{e}}$ estiamtion has been canopy cover (Solberg et al., 2009, Korhonen et al., 2011) but we found that 95-percentile of ALS pulse return position height distribution is better predictor of allometric LAI than canopy cover in Järvselja forests. We used data from Leica ALS50-II scanner which is designed for topographic mapping of ground surface. The Leica ALS50-II laser pulse divides up to four returns when getting in contact with vegetation (Danson et al., 2009). In dense forests first returns of laser pulses are triggered more likely from the upper canopy and last returns more likely from the ground or undergrowth. So, more returns per pulse are generated in taller forests and consequently this increases the probability of a pulse last return to be triggered from the ground (Figure 3 in Straatsma \& Middelkoop, 2006; Figure 1 in Lang et al., 2012). Such an increase of returns per emitted pulse introduces canopy height related dependence into the canopy cover estimates made using discrete-return ALS data. The canopy cover estimates are also influenced by scanning angle (Morsdorf et al., 2006; Korhonen et al., 2011) and gap size distribution of forest canopy (Peduzzi et al., 2012). On the other hand, tree height is used as input variable in the allometric foliage mass models used in this study and the $H_{95}$ from ALS data can be expected to correlate well with allometric LAI. This was confirmed by our tests. 
Now, the question is whether to estimate LAI for Järvselja forest stands from ALSbased forest height or canopy cover? The usual practice is to use canopy cover or transmittance (Morsdorf et al., 2006; Korhonen et al., 2009, Solberg et al., 2009) and the $H_{95}$-based LAI estimation is rather new approach. The largest deviation from the general relationship was observed in pine stands. The reason is that all the pine stands in Järvselja are old and their allometric model-based LAI did not depend much on tree height. A vast majority of allometric foliage mass models are based on tree stem diameter at breast height (Zianis et al., 2005). The good performance of forest height as an estimator for LAI is based on the fact that tree diameter at breast height and the tree height are well correlated. Arumäe \& Lang (2013) show also that live crown base height and live crown length are well correlated with forest stand mean tree diameter at breast height. However, the allometric models estimate foliage mass for single trees not for forest stands. There is a negative feedback from stand density increase to the single tree live crown length (Valentine \& Mäkelä, 2005) and crown volume which is directly related to the amount of foliage on the tree. In denser stands tree crowns tend to be shorter and have smaller volume. Most of the forest stands in Järvselja are regularly managed to keep the forest productive i.e. to maintain an optimal stand density according to good forest management practice while tree height growth depends mainly on site fertility and forest age. While forest height estimation from ALS point cloud is a quite simple linear transformation, the estimation of canopy cover or transmission is not. The complications of ALS- based canopy cover estimation are related to the selection of reference height and pulse return fractions (Lang, 2010). However, there was a small decrease in $P A I_{e, \text { lidar }}$ estimation error when canopy cover was included into model additionally to $H_{95}$. From this we conclude that if ALS- based canopy cover estimates are precise then the best solution for ALS-based LAI estimation models would be the inclusion of forest height or live crown length and canopy cover at the same time.

This study confirmed the results of Kodar et al. (2011) that ALS-based variables are probably the best for LAI mapping in Järvselja hemiboreal mixed species forests followed by forest inventory data and multispectral satellite images. The dependency of reflectance in WorldView-2, Landsat ETM+ and OLI different spectral channels and NDVI with allometric LAI was weak. Stenberg et al. (2004) stated that many spectral vegetation indices showed a fair positive correlation with LAI, but NDVI showed poor sensitivity to changes in LAI as found also by Kuusk et al. (2015) for the same area. Kodar et al. (2011) did not find correlation between LAI and NDVI calculated from SPOT-4 HRV-IR image, but the best correlation was with radiance of red band $\left(R^{2}=0.517\right)$. Kodar et al. (2011) inverted theoretical gap fraction model to estimate LAI but in this study we used allometric foliage mass models from Sweden and Finland and forest management inventory data for the LAI estimation. This indicates that allometric foliage mass models from Scandinavia may not be suitable for Järvselja forests.

\section{Conclusions}

Based on the pilot study for leaf area index and effective plant area index estimation for forests near the SMEAR Estonia flux tower in Järvselja following conclusions can be made. 1) The relationship between spectral reflectance of the forests and allometric LAI (estimated using data from forest inventory database as input for allometric foliage regression models) saturates already at LAI $>3 \mathrm{~m}^{2} \mathrm{~m}^{-2}$ and this complicates the use of multi spectral satellite images for LAI map construction outside the areas of the forest inventory map. 2) 
Allometric LAI can be estimated for birch dominated forests by using a model based on 95-percentile of the ALS pulse return height distribution, but pine dominated forests deviate from the model. Inclusion of canopy cover estimate into the model did not improve the species independent model substantially. 3) We recommend to establish a network of permanent sample plots in the flux footprint of the SMEAR Estonia flux tower for forest growth and gap fraction measurements. The sample plots can serve as reference set for upscaling leaf area index estimates using remote sensing data.

Acknowledgments. Data analysis was supported by Estonian Research Council grants SF0180009Bs11, IUT21-4 and Environmental Conservation and Environmental Technology R\&D Programme project BioAtmos (3.2.0802.11-0043). The authors thank U.S. Geological Survey for free access of Landsat data and Tiit Nilson and Jan Pisek from Tartu Observatory for their useful comments on the manuscript. Andres Kuusk did atmospheric correction for Worldview-2 image. Estonian Network of Forest Research Plots is supported by the Estonian State Forest Management Centre and the Estonian Environmental Investment Centre. The authors thank the two anonymous reviewers for their valuable comments.

\section{References}

Anderson, M.C. 1964. Studies of the woodland light climate. I. The photographic computation of light condition. - Journal of Ecology, $52,27-41$.

Arumäe, T., Lang, M. 2013. A simple model to estimate forest canopy base height from airborne lidar data. - Forestry Studies / Metsanduslikud Uurimused, 58, 46-56.

Béland, M., Baldocchi, D.D., Widlowski, J.L., Fournier, R., Verstraete, M.M. 2014. On seeing the wood from the leaves and the role of voxel size in determining leaf area distribution of forests with terrestrial LiDAR. - Agricultural and Forest Meteorology, 184, 82-97.
Bréda, N.J.J. 2003. Ground-based measurements of leaf area index: a review of methods, instruments and current controversies. - Journal of Experimental Botany, 54(392), 2403-2417.

Cescatti, A. 2007. Indirect estimates of canopy gap fraction based on the linear conversion of hemispherical photographs Methodology and comparison with standard thresholding techniques. - Agricultural and Forest Meteorology, 143, 1-12.

Chen, J.M., Rich, P.M., Gower, T.S., Norman, J.M., Plummer, S. 1997. Leaf area index of boreal forests: Theory, techniques and measurements. - Journal of Geophysical Research, 102, 29429-29444.

Danson, F.M., Morsdorf, F., Koetz, B. 2009. Airborne and terrestrial laser scanning for measuring vegetation canopy structure. - Heritage, G.L., Large, A.R.G. (eds.). Laser scanning for the environmental sciences. Oxford, WileyBlackwell, 201-219.

Frazer, G.W., Canham, C.D., Lertzman, K.P. 1999. Gap Light Analyzer (GLA), Version 2.0: imaging software to extract canopy structure and gap light transmission indices from true-colour fisheye photographs, users manual and program documentation. Simon Fraser University, Burnaby, British Columbia, and the Institute of Ecosystem Studies, Millbrook, New York.

Gower, S.T., Kucharik, C.J., Norman, J.M. 1999. Direct and indirect estimation of leaf area index, fAPAR, and net primary production of terrestrial ecosystems. - Remote Sensing of Environment, 70, 29-51.

Isenburg, M. 2007. LasTools - efficient tools for LiDAR processing. Version 150202. [WWW document]. - URL http://lastools.org [Accessed 14 April 2015].

Jonckheere, I., Fleck, S., Nackaerts, K., Muys, B., Coppin, P., Weiss, M., Baret, F. 2004. Review of methods for in situ leaf area index determination. Part I. Theories, sensors and hemispherical photography. - Agricultural and Forest Meteorology, 121, 19-35.

Jones H.G. 1992. Plants and microclimate. A quantitative approach to environmental plant physiology. Cambridge, Cambridge University Press. 413 pp.

Kangur, A., Korjus, H., Jõgiste, K., Kiviste, A. 2005. A conceptual model of forest stand development based on permanent sample-plot data in Estonia. - Scandinavian Journal of Forest Research, 20(6), 94-101.

Kärkkäinen, L. 2005. Evaluation of performance of tree-level biomass models for forestry modelling and analyses. Finnish Forest Research Institute, Research papers, 940.123 pp. 
Kiviste, A., Hordo, M. 2002. Network of permanent forest growth plots in Estonia. Forestry Studies / Metsanduslikud Uurimused, 37, 43-58.

Kiviste, A., Hordo, M., Kangur, A., Kardakov, A., Laarmann, D., Lilleleht, A., Metslaid, S., Sims, A., Korjus, H. 2015. Monitoring and modeling of forest ecosystems: the Estonian Network of Forest Research Plots. - Forestry Studies / Metsanduslikud Uurimused, 62, 26-38.

Kodar, A., Lang, M., Arumäe, T., Eenmäe, A., Pisek, J., Nilson, T. 2011. Leaf area index mapping with airborne lidar, satellite images and ground measurements in Järvselja VALERI test site. - Forestry Studies / Metsanduslikud Uurimused, 55, 11-32.

Korf, V. 1939. A mathematical definition of forest stands volume growth law. [Příspěvek $\mathrm{k}$ matematické definici vzrůstového zákona hmot lesních porostů.]. Lesnická práce, 18, 339-379. (In Czeckian).

Korhonen, L., Korpela, I., Heiskanen, J., Maltamo, M. 2011. Airborne discrete-return LIDAR data in the estimation of vertical canopy cover, angular canopy closure and leaf area index. - Remote Sensing of Environment, 115, 1065-1080.

Kuusk, A., Lang, M., Kodar, A., Sims, A. 2015. Estimation of leaf area index of hemiboreal forests. - The Open Remote Sensing Journal, 6, 1-10.

Lang, M. 2010. Estimation of crown and canopy cover from airborne lidar data. - Forestry Studies / Metsanduslikud Uurimused, 52, 5-17.

Lang, M., Arumäe, T., Anniste, J. 2012. Estimation of main forest inventory variables from spectral and airborne lidar data in Aegviidu test site, Estonia. - Forestry Studies / Metsanduslikud Uurimused, 56, 27-41.

Lang, M., Kodar, A., Arumäe, T. 2013. Restoration of above canopy reference hemispherical image from below canopy measurements for plant area index estimation in forests. Forestry Studies / Metsanduslikud Uurimused, 59, 13-27.

Lang, M., Kuusk, A., Mõttus, M., Rautiainen, M., Nilson, T. 2010. Canopy gap fraction estimation from digital hemispherical images using sky radiance models and a linear conversion method. - Agricultural and Forest Meteorology, 150, 20-29.

Lang, M., Nilson, T., Kuusk, A., Kiviste, A., Hordo, M. 2007. The performance of foliage mass and crown radius models in forming the input of a forest reflectance model: A test on forest growth sample plots and Landsat 7 ETM+ images. - Remote Sensing of Environment, 110, 445-457.

Leclerc, M.Y., Thurtell, G.W. 1990. Footprint predictions of scalar fluxes using a Markovian analysis. - Boundary-Layer Meteorology, 52, 247-258.

Lefsky, M.A., Cohen, W.B., Acker, S.A., Parker, G.G., Spies, T.A., Harding, D. 1999. Lidar remote sensing of the canopy structure and biophysical properties of Douglas-fir western hemlock forests. - Remote Sensing of Environment, 70, 339-361.

Lefsky, M.A., Cohen, W.B., Parker, G.G., Harding, D.J. 2002. Lidar remote sensing for ecosystem studies. - Bioscience, 52, 19-30.

Liang, S. 2004. Quantitative remote sensing of land surfaces. Hoboken, New Jersey, John Wiley \& Sons, Inc.

Macfarlane, C. 2011. Classification method of mixed pixels does not affect canopy metrics from digital images of forest overstorey. Agricultural and Forest Meteorology, 151, 833-840.

Majasalmi, T., Rautiainen, M., Stenberg, P., Lukeš, P. 2013. An assessment of ground reference methods for estimating LAI of boreal forests. Forest Ecology and Management, 292, 10-18.

Marklund, L.G. 1988. Biomass functions for pine, spruce and birch in Sweden. Swedish University of Agricultural Sciences. Department of Forest Survey. Report 45, 71 pp.

McGaughey, R.J. 2012. FUSION/LDV: Software for LIDAR Data Analysis and Visualization. October 2013 - FUSION Version 3.40. United States Department of Agriculture, Forest Service, Pacific Northwest Research Station.

Miller, J.B. 1967. A formula for average foliage density. - Australian Journal of Botany, 15, 141-144.

Morsdorf, F., Kötz, B., Meier, E., Itten, K.I., Allgöwer, B. 2006. Estimation of LAI and fractional cover from small footprint airborne laser scanning data based on gap fraction. - Remote Sensing of Environment, 104, 50-61.

Myneni, R.B., Keeling, C.D., Tucker, C.J., Asrar, G., Nemani, R.R. 1997. Increased plant growth in the northern high latitudes from 1981 to 1991. Letters to Nature; Nature, 386, 698-702.

Nikinmaa, E., Bäck, J. 2008. Individual. - Boreal forest and climate change. Hari, P., Kulmala, L. (eds.). Springer Science + Business Media B.V. 117-118.

Nilson, T. 1999. Inversion of gap frequency data in forest stands. - Agricultural and Forest Meteorology, 98-99, 437-448.

Noe, S.M. 2013. Simple footprint model for SMEAR Estonia. Department of Plant Physiology. Estonian University of Life Sciences. 6p. Version 27.04.2013, unpublished.

Noe, S.M., Kimmel, V., Hüve, K., Copolovici, L., Portillo-Estrada, M., Püttsepp, Ü., Jõgiste, K., 
Niinemets, Ü., Hörtnagl, L., Wohlfahrt, G. 2011. Ecosystem-scale biosphere-atmosphere interactions of a hemiboreal mixed forest stand at Järvselja, Estonia. - Forest Ecology and Management, 262, 71-81.

Peduzzi, A., Wynne, R.H., Fox, T.R., Nelson, R.F., Thomas, V.A. 2012. Estimating leaf area index in intensively managed pine plantations using airborne laser scanner data. - Forest Ecology and Management, 270, 54-65.

Pope, G., Treitz, P. 2013. Leaf area index (LAI) estimation in boreal mixedwood forest of Ontario, Canada using light detection and ranging ( $\mathrm{Li}-$ DAR) and WorldView-2 imagery. - Remote Sensing, 5, 5040-5063.

R Development Core Team. 2014. R: a language and environment for statistical computing. Vienna, Austria.

Rautiainen, M., Nilson, T., and Lükk, T. 2009. Seasonal reflectance trends of hemiboreal birch forests. - Remote Sensing of Environment, 113, 805-815.

Repola, J. 2008. Biomass equations for birch in Finland. - Silva Fennica, 42, 605-624.

Repola, J. 2009. Biomass equations for Scots pine and Norway spruce in Finland. - Silva Fennica, 43, 625-647.

Rich, P.M. 1990. Characterizing plant canopies with hemispherical photographs. - Remote Sensing Reviews, 5, 13-29.

Richardson, J.J., Moskal, L.M., Kim, S.H. 2009. Modeling approaches to estimate effective leaf area index from aerial discrete-return LIDAR. - Agricultural and Forest Meteorology, 149, 1152-1160.

Ross J. 1981. The radiation regime and architecture of plant stands. The Hague, Dr W. Junk Publishers. $420 \mathrm{pp}$.

Rouse, J.W., Haas, R.H., Schell, J.A., Deering, D.W. 1973. Monitoring vegetation systems in the Great Plains with ERTS. - Third ERTS Symposium, NASA SP-351 I, 309-317.
SMEAR Estonia. 2015. [WWW document]. URL http:/ / smear.emu.ee/ [Accessed 12 June 2015].

Solberg, S., Brunner, A., Hanssen, K.H., Lange, H., Næsset, E., Rautiainen, M., Stenberg, P. 2009. Mapping LAI in a Norway spruce forest using airborne laser scanning. - Remote Sensing of Environment, 113, 2317-2327.

Stenberg, P. 1996. Correcting LAI-2000 estimates for the clumping of needles in shoots of conifers. - Agricultural and Forest Meteorology, 79, $1-8$.

Stenberg, P., Rautiainen, M., Manninen, T., Voipo, P., Smolander, H. 2004. Reduced Simple Ratio better than NDVI for estimating LAI in Finnish pine and spruce stands. - Silva Fennica, 38, 3-14.

Straatsma, M.W., Middelkoop, H. 2006. Airborne laser scanning as a tool for lowland floodplain vegetation monitoring. - Hydrobiologia, 565, 87-103.

Valentine, H.T., Mäkelä, A. 2005. Bridging processbased and empirical approaches to modeling tree growth. - Tree Physiology, 25, 769-779.

Validation of Land European Remote sensing Instruments. 2015. [WWW document]. URL http://w3.avignon.inra.fr/valeri/ [Accessed 12 June 2015].

Wagner, S. 1998. Calibration of grey values of hemispherical photographs for image analysis. Agricultural and Forest Meteorology, 90, 103-117.

Watson, D.J. 1947. Comparative physiological studies in the growth of field crops. I. Variation in net assimilation rate and leaf area between species and varieties, and within and between years. - Annals of Botany, 11, 41-76.

Zianis, D., Muukkonen, P., Mäkipää, R., Mencuccini, M. 2005. Biomass and stem volume equations for tree species in Europe. Silva Fennica Monographs, 4, p. 63. 


\title{
Metsa lehepinnaindeksi hindamine optiliste meetodite ning allomeetriliste mudelitega Järvselja SMEAR-masti neelualal
}

\author{
Marta Mõistus ja Mait Lang
}

Kokkuvõte

Käesoleva töö eesmärgiks oli testida erinevaid meetodeid lehepinnaindeksi (LAI) hindamiseks poolboreaalsetes segametsades Järvseljal. Koostati poolsfääripiltide ja aerolidari andmete põhjal efektiivse taimkatteindeksi PAI $\mathrm{e}_{\mathrm{e}}$ kaart, analüüsiti allomeetriliste lehemassimudelite ja multispektraalsete satelliidipiltide kasutatavust LAI hindamiseks. Uurimispiirkonnaks oli Järvselja Õppe- ja Katsemetskonnas asuva SMEAR-masti neeluala (Noe, 2013), mille ümbruses olevat 25 püsiprooviala kasutati maapealseteks metsa läbipaistvuse mõõtmiseks poolsfääripiltide abil (Joonis 1). Neist kaheksa proovtükki kattus Kodar et al. (2011) töös kasutatud VALERI projekti proovialadega, ülejäänud kuulusid metsa kasvukäigu püsiproovitükkide võrgustikku (Kiviste \& Hordo, 2002; Kangur et al., 2005; Kiviste et al., 2014).

Poolsfääripiltidelt saadud metsa läbipaistvuse nurkjaotuse abil arvutati igale proovitükile valemiga (1) PAI . Aerolidari andmetest arvutati võrastiku läbipaistvus valemitega (2) ja (3), kus $P_{1}$ on esimeste peegelduste arv kõrgemal kui 1,3 m maapinnast, $P_{a}$ on kõikide peegelduste arv kõrgemal kui 1,3 m maapinnast, $P_{t}$ on peegelduste arv kokku ja $P_{t 1}$ on esimeste peegelduste arv kokku.

Järvselja metsade puhul sobis $\mathrm{PAI}_{\mathrm{e}}$ kaardi koostamiseks kõige paremini lidari kõikidel tagasipeegeldustel põhinev läbipaistvuse hinnang (valem (3), joonis 2).
Võrdluses allomeetriliste mudelitega selgus, et lehtpuupuistutes sobib aerolidari andmete põhjal allomeetrilise LAI hindamiseks võrastiku katvusest paremini laserimpulsside peegelduste kõrgusjaotuse 95-protsentiil $H_{95}$ (joonis 4, valem (5), tabel 2). Satelliidipiltidelt saadud spektraalse info ja allomeetrilise LAI vahel ei olnud piisavalt tugevaid seoseid, et neid kasutada LAI kaartide koostamiseks (joonis 5). Varasemas uuringus Järvselja aladel kasutasid aga Kodar et al. (2011) LAI kaardi koostamiseks spektraalset infot ning selle ja käesolevas töös sama ala kohta koostatud PAI kaardi hinnangute vahel oli hea kooskõla (joonis 6). Samas said Kodar et al. (2011) kaardi aluseks olnud proovitükkidele LAI hinnangu metsa läbipaistvuse mudeli pöördülesande lahendamisest ja mitte allomeetrilistest lehemassi regressioonimudelitest.

Seega võib antud töö põhjal väita, et aerolidari andmed on Järvselja segametsade efektiivse lehepinnaindeksi kaardistamiseks multispektraalsetest satelliidipiltidest sobivamad, kuid regulaarselt kogutav multispektraalne info on siiski abiks metsade monitooringul. Pidevalt uuendatav metsa struktuuri kaart on oluline Järvselja SMEAR mastis tehtavate mõõtmiste tõlgendamiseks, seega on soovitav masti neelualale rajada metsa kasvukäigu seireks ja LAI hindamiseks püsiproovitükkide võrgustik. 